\title{
Diel Feeding Cycle and Some Effects of Light on Feeding Intensity of the Mississippi Silverside, Menidia audens, in Clear Lake, California
}

\author{
RaLPH ELston 1 \\ Division of Wildlife and Fisheries Biology \\ University of California, Davis, California 95616 \\ BRUCE BACHEN \\ School of Natural Resources \\ University of Michigan, Ann Arbor, Michigan 48104
}

\begin{abstract}
A study of the diel feeding cycle of 940 Mississippi silversides, Menidia audens Hay, in two 24-hour sampling periods in Clear Lake, California, showed a predominance of crustacean zooplankton in the diet. Ceriodaphnia sp., Daphnia pulex, and emerging dipterans were the most important food items. A pronounced morning feeding peak indicated visual feeding. Evidence of visual feeding is further given by statistically significant ingestion of larger food items at night and decreased feeding during the one moonless night. Occurrence of emerging midges in the diet during the second period indicates possible selective predation.
\end{abstract}

Mississippi silversides, Menidia audens Hay, were introduced into Clear Lake, Lake County, California in 1967 to help control the Clear Lake gnat (Chaoborus astictopus), to reduce algal blooms, and to provide forage for game fishes (Cook and Moore 1970). Since their introduction they have become the most abundant fish in the lake and have spread to a number of reservoirs and streams in the Sacramento-San Joaquin River system, with unknown effects on other fishes (Moyle, Fisher, and $\mathrm{Li}$ 1974). This rapid spread following an introduction is taking place in Oklahoma as well (Sisk and Stephens 1964; Gomez and Lindsay 1972). It has thus become important to learn as much as possible about their biology in order to assess their impact on the waters they invade.

The feeding habits of the Mississippi silverside are known only from studies with small sample sizes. Rice (1942) found that silversides from Reelfoot Lake, Tennessee, were feeding predominately on diatoms. Saunders (1959) found both phytoplankton and zooplankton in the stomachs of silversides from Lake Texoma, Oklahoma. The latter study

\footnotetext{
${ }^{1}$ Present address: Department of Avian and Aquatic Animal Medicine, New York State Veterinary College, Cornell University, Ithaca, New York 14853.
}

indicated that Mississippi silversides have a diminished feeding rate at night.

\section{STUDY AREA}

Clear Lake is the largest natural freshwater lake entirely within California's borders, with a surface area of 17,670 hectares. It is shallow (average depth, $8 \mathrm{~m}$ ), eutrophic, and lies at a low elevation $(440 \mathrm{~m})$ in the Coast Range. Summer temperatures average $20-25 \mathrm{C}$ and the lake is polymictic. The study area was located on the south shore of the upper arm about $500 \mathrm{~m}$ east of the mouth of Cole Creek. It is a shallow sandy bottomed area, with a sparse growth of rooted aquatic plants and a border of tule beds (Scirpus spp.).

\section{METHODS}

The protocol for this diel feeding study was modified from that of Darnell and Meierotto (1962). Collection intervals were established by starving a sample of 100 fish in a closed tank of filtered $(80 \mu$ mesh size) Clear Lake water, maintained at lake temperature $(24-28 \mathrm{C})$. When dissection of a subsample revealed that the guts were empty, zooplankters collected from the lake with a plankton net were introduced. After introduction of food six fish guts were examined every 15 minutes until each stomach was determined to be filled. The time period from food introduction 


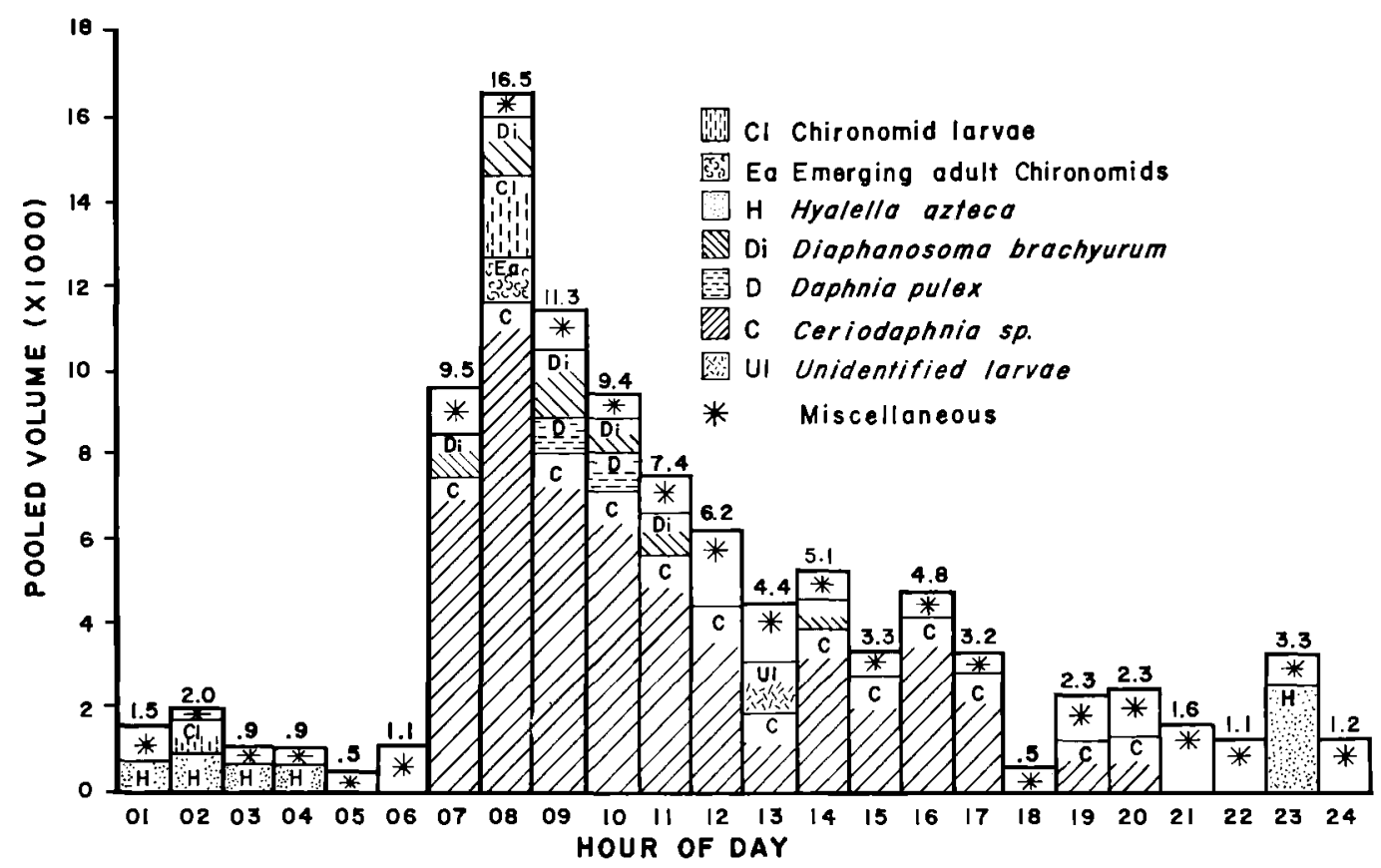

Figure 1.-Diel feeding cycle of the Mississippi silverside, August 19-20, 1973. The bar for each hour represents pooled volume of 20 stomach contents. Numbers over bars refer to percent each hour contributes to total 24-hour volume. Miscellaneous category includes all organisms occurring too infrequently to be graphically represented.

until the stomachs were entirely filled represents the minimum average time elapsed between the entry of a food item into the fish and movement of that food item out of the stomach. This measure of minimum time of movement of food items through the stomach was then used as the sampling interval necessary for complete assessment of the feeding cycle.

Fish were observed to consume food items immediately after introduction of food into the tank. Dissections performed at 15, 30, and 45 minutes showed only partially filled stomachs. All fish examined at the one-hour interval showed food packed through the entire stomach. Accordingly, a one-hour interval was chosen to allow analysis of all food items which entered the stomachs.

Actual sampling consisted of collecting 20 fish (average standard length $58 \mathrm{~mm}$ ) each hour for 24 hours on two separate days with a $10 \mathrm{~m} \times 1.2 \mathrm{~m}, 0.6-\mathrm{cm}-\mathrm{mesh}$ seine. Two sampling periods, one beginning at $1900 \mathrm{~h}$ on
August 19, 1973 (Period I) and the other beginning at $1400 \mathrm{~h}$ on August 23, 1973 (Period II) were selected so that during the first a near full moon was visible during most of the dark hours and that during the second no moon was visible during the dark hours. Immediately after capture the spinal column of the fishes was severed and they were placed in 10 percent formalin solution.

Stomach contents of the 940 fish were later removed and individually examined on a microscope slide at $40 \times$. Food items were identified and counted, and their volumes estimated using a points system similar to that described by Hynes (1950). This is a relatively rapid volumetric estimation in which the average-sized individual of the smallest food species is assigned one point and larger organisms are assigned a proportionately greater number of points. The food species assigned the one point volume was retained as a reference so that allotment of points was consistent throughout the study. Pooled vol- 


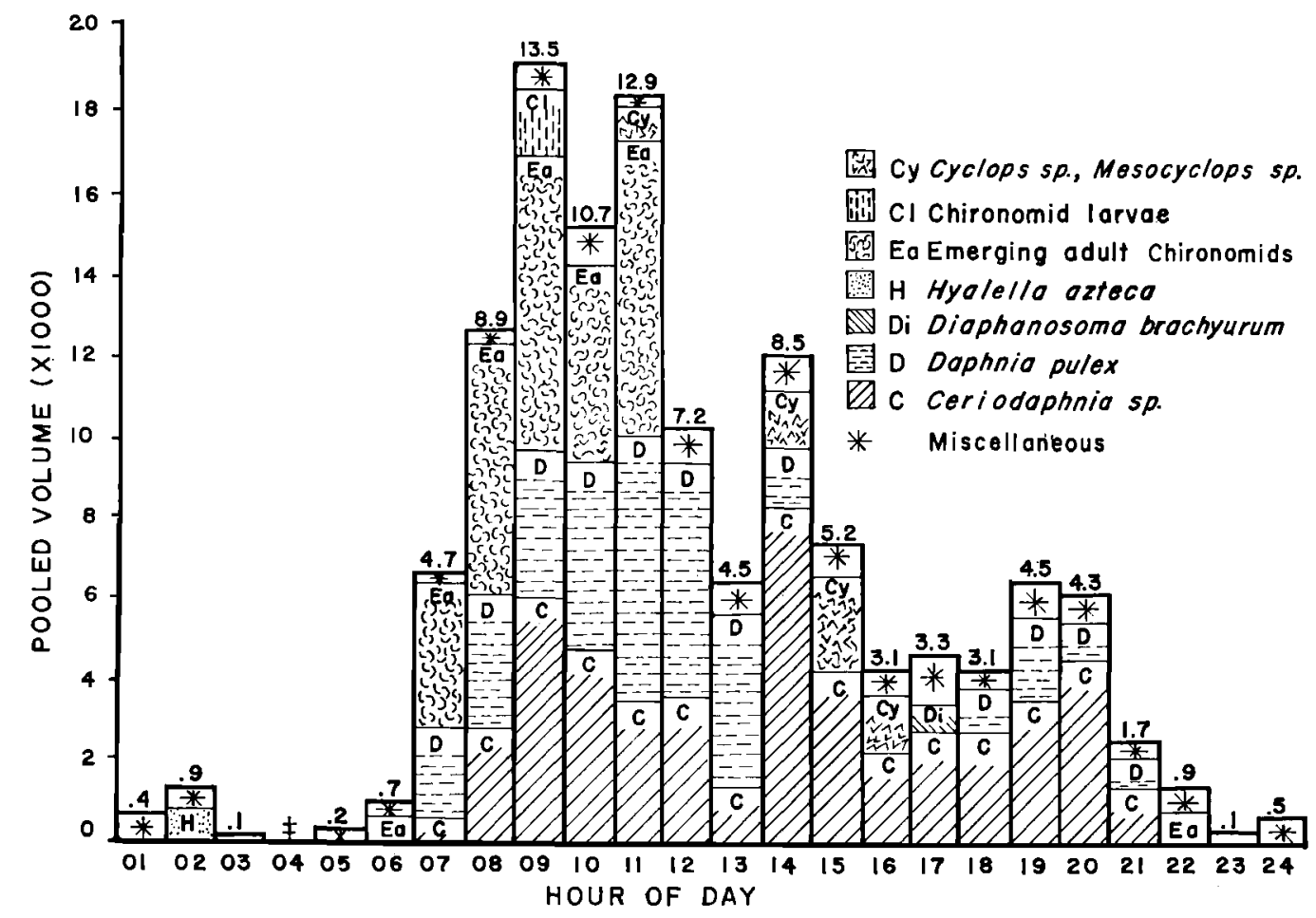

FIGURE 2.-Diel feeding cycle of the Mississippi silverside, August 23-24, 1973. The bar for each hour repre. sents pooled volume of 20 stomach contents. Numbers over bars refer to percent each hour contributes to total 24-hour volume. Miscellaneous category includes all organisms occurring too infrequently to be graphically represented. Data are missing for $0400 \mathrm{~h}$.

umes were obtained by summing the points assigned to all organisms of the same species taken by each of the twenty fish of a given hourly sample.

Differences in food intake between moonless and moonlit nights and between food item size for light and dark periods were tested using the $t$-test based on range (Moore 1957). Using this analysis, each hour was treated as an independent sample, thus providing replication within each of the two sample periods. An index of average food item size was obtained by dividing each total hourly volume by the total number of organisms counted for that hour.

\section{RESULTS}

The stomach analyses showed that the Mississippi silversides in Clear Lake feed primarily on zooplankton (Table 1) with definite daily peaks in both volume and kind of organisms eaten (Figs. 1 and 2). The most important food organisms were Ceriodaphnia sp., Daphnia pulex, and emerging dipterans. The information in Figures 1 and 2 is available in detailed tables from the authors.

Most feeding occurred during the period when the sunlight was directly incident on the water surface at and near the sample site (i.e., the hours between the localized sunrise and sunset). Allowing a one-hour digestion lag time after the last hour of direct sun, the samples taken between $0700 \mathrm{~h}$ and $2000 \mathrm{~h}$ represent fish which were feeding during the hours of direct sunlight. During this time 86 percent of the total daily volume of food was consumed in Period I and 95 percent in Period II.

The feeding peak for both days was rapidly approached after $0700 \mathrm{~h}$, the first hourly sample after which direct sunlight fell on the water (Figs. 1 and 2). The greatest volumes 
TABLE 1.--Percent composition by volume of total daily diet of Mississippi silversides. Each column represents summation of the 24 and 23 hourly pooled volumes for each food item scaled to percentages (Period 1-480 fish; Period II-460 fish). The + indicates occurrence of less than one percent.

\begin{tabular}{|c|c|c|}
\hline \multirow[b]{2}{*}{ Taxon } & \multicolumn{2}{|c|}{ Date and sampling period } \\
\hline & $\begin{array}{l}\text { August } \\
19-20 \\
\text { I }\end{array}$ & $\begin{array}{l}\text { August } \\
23-24 \\
\text { II }\end{array}$ \\
\hline $\begin{array}{l}\text { Cladocera } \\
\text { Bosmina longirostris } \\
\text { Geriodaphnia sp. } \\
\text { Daphnia pulex } \\
\text { Diaphanosoma brachyurum }\end{array}$ & $\begin{array}{r}3 \\
63 \\
5 \\
9\end{array}$ & $\begin{array}{r}1 \\
38 \\
27 \\
2\end{array}$ \\
\hline $\begin{array}{l}\text { Copepoda } \\
\text { Cyclops sp., Mesocyclops sp. } \\
\text { Unidentified nauplii }\end{array}$ & $+\frac{1}{+}$ & $\begin{array}{r}6 \\
+\end{array}$ \\
\hline $\begin{array}{l}\text { Amphipoda } \\
\quad \text { Hyalella azteca }\end{array}$ & 6 & 1 \\
\hline Ostracoda & + & + \\
\hline $\begin{array}{l}\text { Diptera } \\
\text { Chironomid larvae } \\
\text { Emerging Chironomus and } \\
\text { Procladits } \\
\text { Unidentified larvae }\end{array}$ & $\begin{array}{l}6 \\
5 \\
2\end{array}$ & $\begin{array}{r}2 \\
23 \\
+\end{array}$ \\
\hline Rotatoria & + & + \\
\hline
\end{tabular}

of food were obtained from the $0800 \mathrm{~h}$ sample in Period I and the $0900 \mathrm{~h}$ sample Period II. Feeding occurred at a higher level throughout the sunlit hours of Period II than of Period I. The occurrence of Ceriodaphnia sp. closely parallels the total hourly volumes on both days. During Period II, however, the larger size and probable increased availability of Daphnia pulex and emerging dipterans apparently depressed the amount of Ceriodaphnia sp. consumed, especially before $1400 \mathrm{~h}$. Between $0700 \mathrm{~h}$ and $1400 \mathrm{~h}$ in Period II), Daphnia pulex and emerging adult dipterans accounted for 32 percent and 30 percent, respectively, of the total volume for that period while accounting for only 5 percent and 1 percent between $1500 \mathrm{~h}$ and $2000 \mathrm{~h}$.

During the dark hours of Period I, when a nearly full moon was shining, 14 percent of the total daily volume of food was consumed, while only 5 percent of the total daily volume was consumed during the dark moonless hours of Period II. When the $0400 \mathrm{~h}$ samples are eliminated from both periods because of the missing data in Period II, this difference between percent of total daily volume consumed during the dark hours of the two sample pe-

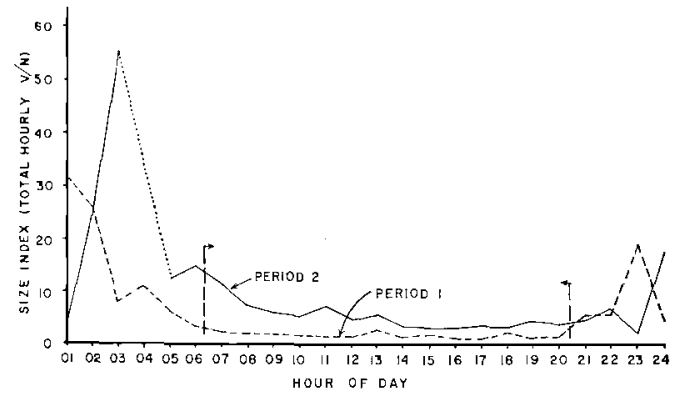

FIGURE 3.-Diurnal changes in the average volume of food organisms consumed by Mississippi silversides. Each point was calculated by dividing pooled hourly volume (V) by pooled hourly numbers (N) of all food items. Vertical dashed lines bracket hours that stomach contents were consumed during direct sunlight on water. Dotted line connects sample hours enclosing missing sample. Period I -moonlit; Period II-moonless.

riods is significant at the 99 percent confidence level.

Night time feeding was primarily on larger, and presumably more visible, organisms. For example, in Period I, 97 percent of the relatively larger and nocturnally active Hyalella azteca were eaten between $2000 \mathrm{~h}$ and $0600 \mathrm{~h}$, while in Period II, 82 percent of the Hyalella were eaten during this period. Figure 3 shows the index of average food item volume plotted by hour for the two sample periods. A sig. nificant difference $(P<0.01)$ was found in the average volume of individual food items selected between daylight and dark hours for each of the two sample periods.

\section{DISCUSSION}

Visual feeding is strongly indicated for the Mississippi silverside in three ways. The first is the dramatic increase in stomach content volume occurring after direct sunlight fell on the water at $0700 \mathrm{~h}$. The second is the statistically significant greater percentage of total daily volume consumed between 2000 $\mathrm{h}$ and $0600 \mathrm{~h}$ during Period I (moonlit) than during Period II (moonless). Visual feeding is also indicated by the consumption of larger organisms during the dark hours (Fig. 3). Chironomid larvae, and Hyalella, are the larger organisms contributing to the stomach contents during the dark hour samples. 
The increased incidence of emerging adult chironomids in Period II is probably closely related to emergence times. Mosquito Abatement District personnel have found evidence for morning emergences in Clear Lake ( $\mathrm{J}$. Prine, personal communication). This is reflected in the high percentages of midges in the $0700 \mathrm{~h}$ to $1100 \mathrm{~h}$ stomachs in Period II. Although prey availability studies are required to demonstrate selective predation, a comparison of Figures 1 and 2 indicates that the silverside may be capable of selective predation as a function of prey availability.

\section{ACKNOWLEDGMENTS}

Dr. Peter Moyle and Dr. Hiram Li advised the study and reviewed the manuscript. Jerry Prine helped identify the food organisms. David Dettman, Wayne Wurtsbaugh, and John Norton reviewed the manuscript.

\section{LITERATURE CITED}

Cook, S. F., and R. L. Moore. 1970. Mississippi silversides, Menidia audens, (Atherinidae), es- tablished in California. Trans. Am. Fish. Soc. $99(1): 70-73$.

Darnell, R. M., and R. R. Meierotto. 1962. Determination of feeding chronology in fishes. Trans. Am. Fish. Soc. 91(3) : 313-320.

Gomez, R., and H, L. Lindsay, JR. 1972. Occurrence of the Mississippi silverside, Menidia au dens (Hay), in Keystone reservoir and the $\mathrm{Ar}$ kansas River. Proc. Okla. Acad. Sci. 52:16-18.

Hynes, H. B. N. 1950. The food of freshwater sticklebacks (Gasterosteus aculeatus and Pygos. teus pungitius), with a review of methods used in studies of the food of fishes. J. Anim. Ecol. 19 (1) : 36-58.

Moore, P. G. 1957. The two sample t-test based on range. Biometrika 44:482-489.

Moyle, P. B., F. W. Fisher, and H. W. Li. 1974 Mississippi silversides and logperch in the Sacramento-San Joaquin River system. Calif. Fish Game 60(3) : 144-147.

Rice, L. A. 1942. The food of seventeen Reelfoot Lake fishes in 1941. Rep. Reelfoot Lake Biol. Sta. 6:4-13.

SaUnders, R. P. 1959. A study of the food of the Mississippi silverside, Menidia audens (Hay), in Lake Texoma. M.S. Thesis. University of Oklahoma. $43 \mathrm{pp}$.

Sisk, M. E., AND R. R. Stephens. 1964. Menidia audens (Pisces: Atherinidae) in Boomer Lake, Oklahoma, and its possible spread in the Arkansas River System. Proc. Okla. Acad. Sci. 44: 71-73. 